\title{
HUBUNGAN RESPONSE TIME SEKSIO SESAREA EMERGENSI KATEGORI 1 DENGAN LUARAN PERINATAL DI RSUP DR. SARDJITO
}

\author{
Tri Gunawan ${ }^{1}$, Ahsanudin Attamimi ${ }^{2}$, Heru Pradjatmo ${ }^{3}$
}

\begin{abstract}
Background: Caesarean section is often applied as a preventif efoort against the continued effects of perinatal asphyxia. The cesarean section (SC) in pregnant woman can be performed in a planned manner with various indications or performed by emergency (emergency) on maternal or fetal indications and or both.

Objective: To study the association of response time in category I emergency caesarean section with perinatal outcomes in Dr. Sardjito hospital and the average response time of category 1 emergency cesarean section in Dr. Sardjito hospital.

Method: This study uses retrospective cohort. Category 1 CS with an indication of fetal accordance with the inclusion criteria was recorded from 1st January 2012 until 31th July 2016, then we find the response time mean as the cut off point of this study to compare with their perinatal outcomes.

Result and Discussion: There were 155 cases out of 386 of emergency CS category 1 met the inclusion criteria during the period 1st January 2012 to 31th July 2016. From the data obtained, the average response time of category 1 emergency CS was $115 \pm 52$ minutes ( 35 - 360 minutes). We found no significant differences in perinatal outcomes in the group's response time $\geq 115$ minutes with a value of $p>0.05$ on the Apgar score, CPAP, infant mortality, ventilator, NICU care, MAS and HIE than those category 1 emergency CS with a response time $<115$ minutes. From multivariate analysis, general anaesthesia was statistically significant against perinatal outcomes Apgar score $<7$ at 5 minutes with $(p=0.044)$. Prematurity in the multivariate analysis was statistically significant against perinatal outcomes Apgar score $\leq 3$ at 1 minute with $(p=0.040)$, Apgar score $<7$ at 5 minutes with $(p=0.025)$ and the use of CPAP with $(p=0.009)$.

Conclusions: Response time category 1 emergency cesarean section in this study did not affect perinatal outcomes. General anesthesia effect on perinatal outcomes Apgar score $<7$ at 5 minutes, whereas the prematurity effect on perinatal outcomes Apgar score $\leq 3$ at 1 minute, Apgar score $<7$ at 5 minutes and the use of CPAP.
\end{abstract}

Keywords: category 1 emergency caesarean section, response time, fetal distress

\section{ABSTRAK}

Latar Belakang: Seksio sesaria sering diterapkan sebagai suatu usaha preventif terhadap terjadinya efek lanjutan akibat asfiksia perinatal. Seksio sesaria (SC) pada ibu hamil dapat dilakukan secara terencana dengan berbagai indikasi atau dilakukan secara emergensi (darurat) atas indikasi ibu atau janin dan atau keduanya.

Tujuan: Mengetahui hubungan response time pada seksio sesarea emergensi kategori I dengan luaran perinatal di RSUP Dr. Sardjito dan rerata response time seksio sesarea emergensi kategori 1 di RSUP Dr. Sardjito.

\footnotetext{
1,2,3 Departemen Obstetri dan Ginekologi, Fakultas Kedokteran, Kesehatan Masyarakat dan Keperawatan Universitas Gadjah Mada
} 
Metode: Penelitian ini menggunakan metode kohort retrospektif. SC kategori 1 dengan indikasi janin yang sesuai dengan kriteria inklusi didata dari 1 Januari 2012 s/d 31 Juli 2016, kemudian dicari rerata response timenya sebagai cut off point penelitian ini untuk dibandingkan luaran perinatalnya

Hasil dan Pembahasan: Didapatkan 155 kasus seksio sesarea emergensi kategori 1 yang masuk kriteria inklusi dari 486 kasus seksio sesarea emergensi kategori 1 selama periode 1 januari 2012 sampai dengan 31 Juli 2016. Dari data yang didapat, rerata response time SC emergensi kategori 1 adalah $115 \pm 52$ menit (35-360 menit). Tidak didapatkan perbedaan bermakna untuk luaran perinatal pada kelompok response time $\geq 115$ menit dengan nilai p>0,05 pada luaran skor Apgar, CPAP, kematian bayi, ventilator, perawatan NICU, MAS dan HIE dibandingkan kelompok seksio emergensi kategori 1 dengan response time <115 menit. Pada analisis multivariat jenis anestesi GA bermakna secara statistik terhadap luaran perinatal skor Apgar $<7$ menit $5(p=0,044)$. Pada analisis multivariat, prematuritas bermakna secara statistik terhadap luaran perinatal skor Apgar $\leq 3$ menit $1(p=0,040)$, skor Apgar $<7$ menit $5(p=0,025)$ dan penggunaan CPAP $(p=0,009)$.

Kesimpulan: Response time seksio sesarea emergensi kategori 1 pada penelitian ini tidak mempengaruhi luaran perinatal. Jenis anestesi GA berpengaruh terhadap luaran perinatal skor Apgar $<7$ menit 5 , sedangkan prematuritas berpengaruh terhadap luaran perinatal skor Apgar $\leq 3$ menit 1 , skor Apgar $<7$ menit 5 dan penggunaan CPAP.

Kata kunci: seksio sesarea emergensi kategori 1, response time, fetal distress

\section{PENDAHULUAN}

Seksio sesarea pada praktek obstetri saat ini, sering diterapkan sebagai suatu usaha preventif terhadap terjadinya efek lanjutan akibat asfiksia perinatal. Keadaan ini merupakan salah satu indikasi umum dan sering menjadi pertimbangan dilakukannya seksio sesarea emerjensi.

Decision to delivery interval (DDI) atau response time didefinisikan sebagai jarak waktu dalam menit dari waktu diputuskannya seksio sesarea sampai dengan bayi lahir. Dari NICE RCOG Caesarean Scetion Guidelines dikatakan untuk response time seksio sesarean kategori 1 adalah 30 menit dan kategori 2 adalah antara 3075 menit. $^{1}$

Secara umum permasalahan yang dihadapi dalam memenuhi response time tersebut adalah persiapan operasi (dari informed consent hingga ruang operasi), konsultasi anestesi, transportasi pasien ke kamar operasi, persiapan anestesi, waktu menunggu keefektifan anestesi bekerja, kehadiran dari personil operasi (dokter kandungan, dokter anestesi, dokter anak/petugas neonatal, perawat bedah) dan kerjasama tim operasi. $^{2}$

Banyak faktor permasalahan di RSUP Dr. Sardjito yang menyebabkan tidak terpenuhinya respon time seksio sesarea emergensi, misalnya jarak kamar bersalin dengan kamar operasi Instalasi Gawat Darurat (IGD) yang cukup jauh, terlalu lama hasil laboratorium muncul, menunggu kedatangan perinatologi, dan jumlah kamar operasi di IGD hanya 3, itupun 1 khusus untuk pasien infeksi. Sehingga dengan adanya faktor tersebut membuat response time terlambat dari waktu yang telah ditentukan dan berakibat kepada luaran perinatal.

Belum adanya penelitian mengenai response time seksio emergensi kategori 1 di RSUP Dr. Sardjito hingga saat ini mendorong penulis untuk mengangkat permasalahan tersebut. Hal ini menjadi sangat penting terutama pada masa 
setelah akreditasi $\mathrm{JCl}$ yang diterapkan di RSUP Dr. Sardjito dalam memenuhi standar pelayanan yang berkualitas kepada pasien. Adapun untuk response time operasi seksio sesarea emergensi kategori 1 sesuai Standar Pelayanan Operasional RSUP Dr. Sardjito yang telah disepakati bersama yaitu interval waktu 30 menit dari penegakan diagnosis sampai dengan kelahiran neonatal dan 75 menit untuk kategori 2 .

\section{METODE}

Rancangan penelitian yang digunakan adalah studi kohort retrospektif dengan melihat data dari rekam medik pasien yang memenuhi kriteria inklusi dan ekslusi di RSUP Dr. Sardjito sejak 1 Januari 2012 sampai dengan 31 Juli 2016. Adapun kriteria inklusinya adalah pasien yang dilakukan seksio sesarea emergensi kategori I dengan indikasi janin dan usia kehamilan $\geq 34$ minggu. Ibu dengan kelainan kardiovaskular seperti hipertensi dalam kehamilan, kelainan jantung, stroke, kelainan metabolik dan janin dengan kelainan mayor maupun minor serta pasien yang datanya tidak lengkap kami eksklusikan. Dari data tersebut kami cari rerata response timenya untuk dijadikan cut of point kemudian dilihat luaran perinatalnya. Luaran perinatal yang dinilai adalah skor Apgar $\leq 3$ menit 1, skor Apgar $<7$ menit 5, penggunaan CPAP (Continuous Positive Airway Pressure), kematian bayi, penggunaan ventilator, perawatan NICU (Neonatal Intensive Care Unit), MAS(Sindorma Aspirasi Mekonium), dan HIE (Hypoxic Ischemic Encephalopathy). Jenis anastesi, riwayat operasi sebelumnya, ketuban pecah dini, prematuritas, persalinan lama dan vakum ekstraksi gagal merupakan variabel bebas pada penelitian ini.

Semua data yang didapat pada penelitian ini diolah melalui proses pengolahan data yaitu editing, coding, processing, dan cleaning.
Kemudian setelah proses pengolahan data dilakukan data dianalisis dengan menggunakan software SPSS 23.

Untuk melihat karaketristik subjek penelitian, kami menggunakan analisis deskriptif univariat. Untuk mengetahui hubungan proporsi response time dan varibel bebas (jenis anestesi, riwayat operasi sebelumnya, ketuban pecah dini, prematuritas, persalinan lama dan vakum ekstraksi gagal) dengan luaran perinatal kami menggunakan analisis bivariat Chi square.

Setelah mendapatkan hasil dari analisis bivariat, kami melakukan analisis multivariat Regresi Logistik metode backward dengan memasukkan semua variabel kemudian pada step terakhir kita lihat variabel mana yang signifikan secara statistik, dengan melihat nilai $p$, odds ratio dan indeks kepercayaan (IK).

\section{HASIL DAN PEMBAHASAN}

Dari data rekam medik didapatkan 155 kasus yang sesuai kriteria inklusi dan eksklusi dari total 486 kasus seksio sesarea emergensi kategori 1. Dari data tersebut didapatkan rerata response time SC emergensi kategori 1 adalah $115 \pm 52$ menit (35-360 menit) dengan persentase paling besar pada response time $91-150$ menit (41,9\%) yang dapat dilihat pada tabel 1 .

Tabel 1. Response time seksio sesarea emergensi kategori 1 pada subjek penelitian

\begin{tabular}{lcc}
\hline Response time & $\mathrm{n}$ & $\%$ \\
\hline $30-90$ menit & 62 & 40 \\
$91-150$ menit & 65 & 41,9 \\
$151-210$ menit & 22 & 14,2 \\
$211-270$ menit & 3 & 1,9 \\
$>270$ menit & 3 & 1,9 \\
\hline Total & 155 & 100 \\
\hline
\end{tabular}


Tabel 2. Karakteristik Pasien

\begin{tabular}{|c|c|c|c|c|c|c|}
\hline & Variabel & $\geq 115$ menit & $<115$ menit & $\mathrm{n}$ & $\%$ & $p$ \\
\hline Usia & & & & & & 0,706 \\
\hline$\bullet$ & $<21$ tahun & 3 & 2 & 5 & 3,2 & \\
\hline$\bullet$ & 21-30 tahun & 39 & 41 & 80 & 51,6 & \\
\hline$\bullet$ & 31-40tahun & 27 & 37 & 64 & 41,3 & \\
\hline$\bullet$ & $>40$ tahun & 2 & 4 & 6 & 3,9 & \\
\hline Parita & & & & & & 0,173 \\
\hline$\bullet$ & 0 & 44 & 39 & 83 & 53,5 & \\
\hline$\bullet$ & 1 & 21 & 31 & 52 & 33,5 & \\
\hline$\bullet$ & 2 & 5 & 9 & 14 & 9 & \\
\hline • & $\geq 3$ & 1 & 5 & 6 & 3,9 & \\
\hline Usia I & hamilan & & & & & 0,043 \\
\hline$\bullet$ & 34-36 minggu & 9 & 16 & 25 & 16,1 & \\
\hline$\bullet$ & $37-40$ minggu & 45 & 60 & 105 & 67,7 & \\
\hline$\bullet$ & $>40$ minggu & 17 & 8 & 25 & 16,1 & \\
\hline Indik & i SC & & & & & 0,079 \\
\hline$\bullet$ & Fetal distress & 71 & 82 & 149 & 96,1 & \\
\hline$\bullet$ & Prolaps tali pusat & 0 & 6 & 6 & 3,9 & \\
\hline Berat & ayi & & & & & 0,089 \\
\hline$\bullet$ & $<2500 \mathrm{gr}$ & 11 & 23 & 34 & 21,9 & \\
\hline$\bullet$ & $2500-3500 \mathrm{gr}$ & 48 & 54 & 102 & 65,8 & \\
\hline$\bullet$ & $3500-4500 \mathrm{gr}$ & 12 & 7 & 19 & 12,3 & \\
\hline Asal & & & & & & 0,003 \\
\hline$\bullet$ & IGD & 36 & 62 & 98 & 63,2 & \\
\hline$\bullet$ & IMP/bangsal & 35 & 22 & 57 & 36,8 & \\
\hline
\end{tabular}

Dari tabel 2 dapat dilihat karakteristik pasien berdasarkan usia sebagian besar 21-30 tahun (51,6\%), sebagian besar primigravida $(53,5 \%)$. Untuk usia kehamilan, sebagian besar 37-40 minggu (67,7\%), usia 34-36 minggu $(16,1 \%)$. Indikasi SC paling banyak pada penelitian ini yaitu fetal distress $(96,1 \%)$ diikuti prolaps tali pusat 6 kasus (3,9\%). Sedangkan untuk asal pasien yang dilakukan seksio sesarea emergensi terbanyak dari IGD $(63,2 \%)$ dan bangsal IMP (kamar bersalin) (36,8\%). 
Tabel 3. Faktor-faktor yang berhubungan dengan luaran perinatal skor Apgar menit $1 \leq 3$

\begin{tabular}{|c|c|c|c|c|c|c|c|c|}
\hline \multirow{2}{*}{ Variabel } & & \multicolumn{4}{|c|}{ Skor APGAR menit 1} & \multirow{2}{*}{ RR } & \multirow{2}{*}{ IK 95\% } & \multirow{2}{*}{$P$} \\
\hline & & & $=3$ & & $>3$ & & & \\
\hline \multirow[t]{2}{*}{ Response time } & $\geq 115$ menit & 4 & $5,6 \%$ & 67 & $94,4 \%$ & 0,364 & $0,124-1,067$ & 0,051 \\
\hline & $<115$ menit & 13 & $15,5 \%$ & 71 & $84,5 \%$ & & & \\
\hline \multirow[t]{2}{*}{ Riw SC } & Ya & 1 & $4,5 \%$ & 21 & $95,5 \%$ & 0,378 & $0,053-2,707$ & 0,266 \\
\hline & Tidak & 16 & $12,0 \%$ & 117 & $88,0 \%$ & & & \\
\hline \multirow[t]{2}{*}{ Jenis anestesi } & GA & 3 & $37,5 \%$ & 5 & $62,5 \%$ & 3,938 & $1,41-10,96$ & $0,044^{*}$ \\
\hline & Spinal & 14 & $9,5 \%$ & 133 & $90,5 \%$ & & & \\
\hline \multirow[t]{2}{*}{ KPD } & Ya & 2 & $9,5 \%$ & 19 & $90,5 \%$ & 0,851 & $0,209-3,457$ & 0,587 \\
\hline & Tidak & 15 & $11,2 \%$ & 119 & $88,8 \%$ & & & \\
\hline \multirow[t]{2}{*}{ Prematuritas } & Ya & 6 & $25,0 \%$ & 18 & $75,0 \%$ & 2,977 & $1,217-7,283$ & $0,028^{*}$ \\
\hline & Tidak & 11 & $8,4 \%$ & 120 & $91,6 \%$ & & & \\
\hline \multirow[t]{2}{*}{ Vakum_gagal } & Ya & 1 & $50,0 \%$ & 1 & $50,0 \%$ & 4,781 & $1,11-20,62$ & 0,208 \\
\hline & Tidak & 16 & $10,5 \%$ & 137 & $89,5 \%$ & & & \\
\hline \multirow[t]{2}{*}{ Persalinan_lama } & Ya & 3 & $8,8 \%$ & 31 & $91,2 \%$ & 0,763 & $0,233-2,500$ & 0,462 \\
\hline & Tidak & 14 & $11,6 \%$ & 107 & $88,4 \%$ & & & \\
\hline
\end{tabular}

Tabel 3. Faktor-faktor yang berhubungan dengan luaran perinatal skor Apgar menit $1 \leq 3$

\begin{tabular}{|c|c|c|c|c|c|c|c|c|}
\hline \multirow{3}{*}{ Variabel } & & \multicolumn{4}{|c|}{ Skor APGAR menit 1} & \multirow{3}{*}{$\mathrm{RR}$} & \multirow{3}{*}{ IK 95\% } & \multirow{3}{*}{$P$} \\
\hline & & \multicolumn{2}{|c|}{$<=3$} & \multicolumn{2}{|c|}{$>3$} & & & \\
\hline & & $\mathrm{n}$ & $\%$ & $\mathrm{n}$ & $\%$ & & & \\
\hline \multirow[t]{2}{*}{ Response time } & $\geq 115$ menit & 4 & $5,6 \%$ & 67 & $94,4 \%$ & 0,364 & $0,124-1,067$ & 0,051 \\
\hline & $<115$ menit & 13 & $15,5 \%$ & 71 & $84,5 \%$ & & & \\
\hline \multirow[t]{2}{*}{ Riw SC } & Ya & 1 & $4,5 \%$ & 21 & $95,5 \%$ & 0,378 & $0,053-2,707$ & 0,266 \\
\hline & Tidak & 16 & $12,0 \%$ & 117 & $88,0 \%$ & & & \\
\hline \multirow{2}{*}{ Jenis anestesi } & GA & 3 & $37,5 \%$ & 5 & $62,5 \%$ & 3,938 & $1,41-10,96$ & $0,044 *$ \\
\hline & Spinal & 14 & $9,5 \%$ & 133 & $90,5 \%$ & & & \\
\hline \multirow[t]{2}{*}{ KPD } & Ya & 2 & $9,5 \%$ & 19 & $90,5 \%$ & 0,851 & $0,209-3,457$ & 0,587 \\
\hline & Tidak & 15 & $11,2 \%$ & 119 & $88,8 \%$ & & & \\
\hline \multirow[t]{2}{*}{ Prematuritas } & Ya & 6 & $25,0 \%$ & 18 & $75,0 \%$ & 2,977 & $1,217-7,283$ & $0,028^{*}$ \\
\hline & Tidak & 11 & $8,4 \%$ & 120 & $91,6 \%$ & & & \\
\hline \multirow[t]{2}{*}{ Vakum_gagal } & Ya & 1 & $50,0 \%$ & 1 & $50,0 \%$ & 4,781 & $1,11-20,62$ & 0,208 \\
\hline & Tidak & 16 & $10,5 \%$ & 137 & $89,5 \%$ & & & \\
\hline \multirow[t]{2}{*}{ Persalinan_lama } & $\mathrm{Ya}$ & 3 & $8,8 \%$ & 31 & $91,2 \%$ & 0,763 & $0,233-2,500$ & 0,462 \\
\hline & Tidak & 14 & $11,6 \%$ & 107 & $88,4 \%$ & & & \\
\hline
\end{tabular}


Tabel 4. Faktor-faktor yang berhubungan dengan luaran perinatal skor Apgar menit $5<7$

\begin{tabular}{|c|c|c|c|c|c|c|c|c|}
\hline \multirow{3}{*}{ Variabel } & & \multicolumn{4}{|c|}{ Skor APGAR menit 5} & \multirow{3}{*}{$\mathrm{RR}$} & \multirow{3}{*}{ IK 95\% } & \multirow{3}{*}{$p$} \\
\hline & & \multicolumn{2}{|c|}{$<7$} & \multicolumn{2}{|c|}{$\geq 7$} & & & \\
\hline & & $\mathrm{n}$ & $\%$ & $\mathrm{n}$ & $\%$ & & & \\
\hline \multirow[t]{2}{*}{ Response time } & $\geq 115$ menit & 8 & 11,3 & 63 & 88,7 & 0,676 & $0,301-1,518$ & 0,337 \\
\hline & $<115$ menit & 14 & 16,7 & 70 & 83,3 & & & \\
\hline \multirow[t]{2}{*}{ Riw SC } & Ya & 4 & 18,2 & 18 & 81,8 & 1,343 & $0,502-3,598$ & 0,381 \\
\hline & Tidak & 18 & 13,5 & 115 & 86,5 & & & \\
\hline \multirow[t]{2}{*}{ Jenis anestesi } & $\mathrm{GA}$ & 4 & 50 & 4 & 50 & 4,083 & $1,804-9,243$ & $0,015^{*}$ \\
\hline & Spinal & 18 & 12,2 & 129 & 87,8 & & & \\
\hline \multirow[t]{2}{*}{ KPD } & Ya & 2 & 9,5 & 19 & 90,5 & 0,638 & $0,161-2,533$ & 0,396 \\
\hline & Tidak & 20 & 14,9 & 114 & 85,1 & & & \\
\hline \multirow[t]{2}{*}{ Prematuritas } & Ya & 8 & 33,3 & 16 & 66,7 & 3,119 & $1,471-6,615$ & $0,008^{*}$ \\
\hline & Tidak & 14 & 10,7 & 117 & 89,3 & & & \\
\hline \multirow[t]{2}{*}{ Vakum_gagal } & Ya & 0 & 0 & 2 & 100 & 1,685 & $0,296-9,587$ & 0,735 \\
\hline & Tidak & 22 & 14,4 & 131 & 85,6 & & & \\
\hline \multirow[t]{2}{*}{ Persalinan_lama } & Ya & 4 & 11,8 & 30 & 88,2 & 0,791 & $0,287-2,181$ & 0,443 \\
\hline & Tidak & 18 & 14,9 & 103 & 85,1 & & & \\
\hline
\end{tabular}

Tabel 5. Faktor-faktor yang berhubungan dengan luaran perinatal penggunaan CPAP pada neonatus

\begin{tabular}{|c|c|c|c|c|c|c|c|c|}
\hline \multirow{3}{*}{ Variabel } & & \multicolumn{4}{|c|}{ CPAP } & \multirow{3}{*}{$\mathrm{RR}$} & \multirow{3}{*}{ IK 95\% } & \multirow{3}{*}{$p$} \\
\hline & & \multicolumn{2}{|c|}{$\mathrm{Ya}$} & \multicolumn{2}{|c|}{ Tidak } & & & \\
\hline & & $\mathrm{n}$ & $\%$ & $n$ & $\%$ & & & \\
\hline \multirow[t]{2}{*}{ Response time } & $\geq 115$ menit & 7 & 9,9 & 64 & 90,1 & 0,753 & $0,308-1,840$ & 0,531 \\
\hline & $<115$ menit & 11 & 13,1 & 73 & 86,9 & & & \\
\hline \multirow[t]{2}{*}{ Riw SC } & Ya & 2 & 9,1 & 20 & 90,9 & 0,756 & $0,187-3,062$ & 0,512 \\
\hline & Tidak & 16 & 12 & 117 & 88 & & & \\
\hline \multirow[t]{2}{*}{ Jenis anestesi } & GA & 2 & 25 & 6 & 75 & 2,297 & $0,635-8,313$ & 0,234 \\
\hline & Spinal & 16 & 10,9 & 131 & 89,1 & & & \\
\hline \multirow[t]{2}{*}{ KPD } & Ya & 0 & 0 & 21 & 100 & 0,311 & $0,044-2,213$ & 0,061 \\
\hline & Tidak & 18 & 13,4 & 116 & 86,6 & & & \\
\hline \multirow[t]{2}{*}{ Prematuritas } & Ya & 7 & 29,2 & 17 & 70,8 & 3,473 & $1,497-8,060$ & $0,009 *$ \\
\hline & Tidak & 11 & 8,4 & 120 & 91,6 & & & \\
\hline \multirow[t]{2}{*}{ Vakum_gagal } & Ya & 0 & 0 & 2 & 100 & 2,039 & $0,355-11,723$ & 0,781 \\
\hline & Tidak & 18 & 11,8 & 135 & 88,2 & & & \\
\hline \multirow[t]{2}{*}{ Persalinan_lama } & Ya & 1 & 2,9 & 33 & 97,1 & 0,209 & $0,029-1,517$ & 0,059 \\
\hline & Tidak & 17 & 14 & 104 & 86 & & & \\
\hline
\end{tabular}


Tabel 6. Faktor-faktor yang berhubungan dengan ematian bayi

\begin{tabular}{|c|c|c|c|c|c|c|c|c|}
\hline \multirow{3}{*}{ Variabel } & \multicolumn{5}{|c|}{ Kematian bayi } & \multirow{3}{*}{ RR } & \multirow{3}{*}{ IK 95\% } & \multirow{3}{*}{$\mathrm{p}$} \\
\hline & & \multicolumn{2}{|c|}{ Ya } & \multicolumn{2}{|c|}{ Tidak } & & & \\
\hline & & $\mathrm{n}$ & $\%$ & $\mathrm{n}$ & $\%$ & & & \\
\hline \multirow[t]{2}{*}{ Response time } & $\geq 115$ menit & 6 & 8,5 & 65 & 91,5 & 1,014 & $0,357-2,880$ & 0,979 \\
\hline & $<115$ menit & 7 & 8,3 & 77 & 91,7 & & & \\
\hline \multirow[t]{2}{*}{ Riw SC } & Ya & 1 & 4,5 & 21 & 95,5 & 0,504 & $0,069-3,684$ & 0,421 \\
\hline & Tidak & 12 & 9 & 121 & 91 & & & \\
\hline \multirow[t]{2}{*}{ Jenis anestesi } & GA & 2 & 25 & 6 & 75 & 3,341 & $0,885-12,607$ & 0,136 \\
\hline & Spinal & 11 & 7,5 & 136 & 92,5 & & & \\
\hline \multirow[t]{2}{*}{ KPD } & Ya & 2 & 9,5 & 19 & 90,5 & 1,160 & $0,276-4,871$ & 0,551 \\
\hline & Tidak & 11 & 8,2 & 123 & 91,8 & & & \\
\hline \multirow[t]{2}{*}{ Prematuritas } & Ya & 4 & 16,7 & 20 & 83,3 & 2,426 & $0,812-7,248$ & 0,120 \\
\hline & Tidak & 9 & 6,9 & 122 & 93,1 & & & \\
\hline \multirow[t]{2}{*}{ Vakum_gagal } & Ya & 1 & 50 & 1 & 50 & 6,375 & $1,439-28,245$ & 0,161 \\
\hline & Tidak & 12 & 7,8 & 141 & 92,2 & & & \\
\hline \multirow[t]{2}{*}{ Persalinan_lama } & Ya & 3 & 8,8 & 31 & 91,2 & 1,068 & $0,311-3,663$ & 0,575 \\
\hline & Tidak & 10 & 8,3 & 111 & 91,7 & & & \\
\hline
\end{tabular}

Tabel 7. Faktor-faktor yang berhubungan dengan penggunaan ventilator

\begin{tabular}{|c|c|c|c|c|c|c|c|c|}
\hline \multirow{3}{*}{ Variabel } & \multicolumn{5}{|c|}{ Ventilator } & \multirow{3}{*}{ RR } & \multirow{3}{*}{ IK 95\% } & \multirow{3}{*}{$p$} \\
\hline & & \multicolumn{2}{|c|}{ Ya } & \multicolumn{2}{|c|}{ Tidak } & & & \\
\hline & & $\mathrm{n}$ & $\%$ & $\mathrm{n}$ & $\%$ & & & \\
\hline \multirow[t]{2}{*}{ Response time } & $\geq 115$ menit & 8 & 11,3 & 63 & 88,7 & 1,577 & $0,574-4,332$ & 0,372 \\
\hline & $<115$ menit & 6 & 7,1 & 78 & 92,9 & & & \\
\hline \multirow[t]{2}{*}{ Riw SC } & Ya & 0 & 0 & 22 & 100 & 0,375 & $0,052-2,708$ & 0,106 \\
\hline & Tidak & 14 & 10,5 & 119 & 89,5 & & & \\
\hline \multirow[t]{2}{*}{ Jenis anestesi } & GA & 2 & 25 & 6 & 75 & 3,063 & $0,821-11,430$ & 0,155 \\
\hline & Spinal & 12 & 8,2 & 135 & 91,8 & & & \\
\hline \multirow[t]{2}{*}{ KPD } & Ya & 2 & 9,5 & 19 & 90,5 & 1,063 & $0,256-4,420$ & 0,595 \\
\hline & Tidak & 12 & 9 & 122 & 91 & & & \\
\hline \multirow[t]{2}{*}{ Prematuritas } & Ya & 4 & 16,7 & 20 & 83,3 & 2,426 & $0,812-7,248$ & 0,120 \\
\hline & Tidak & 9 & 6,9 & 122 & 93,1 & & & \\
\hline \multirow[t]{2}{*}{ Vakum_gagal } & Ya & 0 & 0 & 2 & 100 & 2,583 & $0,443-15,079$ & 0,827 \\
\hline & Tidak & 14 & 9,2 & 141 & 90,8 & & & \\
\hline \multirow[t]{2}{*}{ Persalinan_lama } & Ya & 1 & 2,9 & 33 & 97,1 & 0,274 & $0,037-2,019$ & 0,141 \\
\hline & Tidak & 13 & 10,7 & 108 & 89,3 & & & \\
\hline
\end{tabular}


Tabel 8. Faktor-faktor yang berhubungan dengan perawatan

\begin{tabular}{|c|c|c|c|c|c|c|c|c|}
\hline \multirow{3}{*}{ Variabel } & \multicolumn{5}{|c|}{$\mathrm{NICU}$} & \multirow{3}{*}{$\mathrm{RR}$} & \multirow{3}{*}{ IK 95\% } & \multirow{3}{*}{$p$} \\
\hline & & \multicolumn{2}{|c|}{ Ya } & \multicolumn{2}{|c|}{ Tidak } & & & \\
\hline & & $\mathrm{n}$ & $\%$ & $\mathrm{n}$ & $\%$ & & & \\
\hline \multirow[t]{2}{*}{ Response time } & $\geq 115$ menit & 8 & 11,3 & 63 & 88,7 & 1,352 & $0,516-3,545$ & 0,538 \\
\hline & $<115$ menit & 7 & 8,3 & 77 & 91,7 & & & \\
\hline \multirow[t]{2}{*}{ Riw SC } & Ya & 0 & 0 & 22 & 100 & 0,352 & $0,049-2,529$ & 0,089 \\
\hline & Tidak & 15 & 11,3 & 118 & 88,7 & & & \\
\hline \multirow[t]{2}{*}{ Jenis anestesi } & GA & 2 & 25 & 6 & 75 & 2,827 & $0,765-10,452$ & 0,174 \\
\hline & Spinal & 13 & 8,8 & 134 & 91,2 & & & \\
\hline \multirow[t]{2}{*}{ Ketuban pecah dini } & Ya & 2 & 9,5 & 19 & 90,5 & 0,962 & $0,238-4,045$ & 0,670 \\
\hline & Tidak & 13 & 9,7 & 121 & 90,3 & & & \\
\hline \multirow[t]{2}{*}{ Prematuritas } & Ya & 5 & 20,8 & 19 & 79,2 & 2,729 & $1,023-7,282$ & 0,059 \\
\hline & Tidak & 10 & 7,6 & 121 & 92,4 & & & \\
\hline \multirow[t]{2}{*}{ Vakum_gagal } & Ya & 0 & 0 & 2 & 100 & 2,422 & $0,417-14,072$ & 0,815 \\
\hline & Tidak & 15 & 9,8 & 138 & 90,2 & & & \\
\hline \multirow[t]{2}{*}{ Persalinan_lama } & Ya & 3 & 8,8 & 31 & 91,2 & 0,890 & $0,266-2,973$ & 0,574 \\
\hline & Tidak & 12 & 9,9 & 109 & 90,1 & & & \\
\hline
\end{tabular}

Tabel 9. Faktor-faktor yang berhubungan dengan Sindroma Aspirasi Meconium

\begin{tabular}{|c|c|c|c|c|c|c|c|c|}
\hline \multirow{3}{*}{ Variabel } & & \multicolumn{4}{|c|}{ MAS } & \multirow{3}{*}{$\mathrm{RR}$} & \multirow{3}{*}{ IK 95\% } & \multirow{3}{*}{$P$} \\
\hline & & \multicolumn{2}{|c|}{$\mathrm{Ya}$} & \multicolumn{2}{|c|}{ Tidak } & & & \\
\hline & & $\mathrm{n}$ & $\%$ & $\mathrm{n}$ & $\%$ & & & \\
\hline \multirow[t]{2}{*}{ Response time } & $\geq 115$ menit & 4 & 5,6 & 67 & 94,4 & 0,946 & $0,264-3,391$ & 0,605 \\
\hline & $<115$ menit & 5 & 6 & 79 & 94 & & & \\
\hline \multirow[t]{2}{*}{ Riw SC } & Ya & 1 & 4,5 & 21 & 95,5 & 0,756 & $0,099-5,750$ & 0,626 \\
\hline & Tidak & 8 & 6 & 125 & 94 & & & \\
\hline \multirow[t]{2}{*}{ Jenis anestesi } & GA & 0 & 0 & 8 & 100 & 1,490 & $\begin{array}{c}0,211- \\
10,508\end{array}$ & 0,613 \\
\hline & Spinal & 9 & 6,1 & 138 & 93,9 & & & \\
\hline \multirow[t]{2}{*}{ KPD } & Ya & 0 & 0 & 21 & 100 & 0,591 & $0,079-4,402$ & 0,260 \\
\hline & Tidak & 9 & 6,7 & 125 & 93,3 & & & \\
\hline \multirow[t]{2}{*}{ Prematuritas } & Ya & 0 & 0 & 24 & 100 & 0,512 & $0,068-3,826$ & 0,210 \\
\hline & Tidak & 9 & 6,9 & 122 & 93,1 & & & \\
\hline \multirow[t]{2}{*}{ Vakum_gagal } & $\mathrm{Ya}$ & 0 & 0 & 2 & 100 & 2,422 & $\begin{array}{l}0,417- \\
14,072\end{array}$ & 0,815 \\
\hline & Tidak & 15 & 9,8 & 138 & 90,2 & & & \\
\hline \multirow[t]{2}{*}{ Persalinan_lama } & Ya & 2 & 5,9 & 32 & 94,1 & 1,017 & $0,221-4,671$ & 0,627 \\
\hline & Tidak & 7 & 5,8 & 114 & 94,2 & & & \\
\hline
\end{tabular}


Tabel 10. Faktor-faktor yang berhubungan dengan HIE (Hypoxic Ischemic Encephopathy) pada variabel bebas (response time) dan variabel luar.

\begin{tabular}{|c|c|c|c|c|c|c|c|c|}
\hline \multirow{3}{*}{ Variabel } & & \multicolumn{4}{|c|}{ HIE } & \multirow{3}{*}{$\mathrm{RR}$} & \multirow{3}{*}{ IK 95\% } & \multirow{3}{*}{$\mathrm{P}$} \\
\hline & & \multicolumn{2}{|c|}{$\mathrm{Ya}$} & \multicolumn{2}{|c|}{ Tidak } & & & \\
\hline & & $\mathrm{n}$ & $\%$ & $\mathrm{n}$ & $\%$ & & & \\
\hline \multirow[t]{2}{*}{ Response time } & $\geq 115$ menit & 3 & 4,2 & 68 & 95,8 & 1,775 & $0,305-10,326$ & 0,421 \\
\hline & $<115$ menit & 2 & 2,4 & 82 & 97,6 & & & \\
\hline \multirow[t]{2}{*}{ Riw SC } & Ya & 0 & 0 & 22 & 100 & 0,938 & $0,118-7,444$ & 0,460 \\
\hline & Tidak & 5 & 3,8 & 128 & 96,2 & & & \\
\hline \multirow[t]{2}{*}{ Jenis anestesi } & GA & 0 & 0 & 8 & 100 & 2,483 & $0,330-18,680$ & 0,764 \\
\hline & Spinal & 5 & 3,4 & 142 & 96,6 & & & \\
\hline \multirow[t]{2}{*}{ KPD } & Ya & 0 & 0 & 21 & 100 & 0,986 & $0,124-7,813$ & 0,478 \\
\hline & Tidak & 5 & 3,7 & 129 & 96,3 & & & \\
\hline \multirow[t]{2}{*}{ Prematuritas } & Ya & 1 & 4,2 & 23 & 95,8 & 1,365 & $0,159-11,687$ & 0,574 \\
\hline & Tidak & 4 & 3,1 & 127 & 96,9 & & & \\
\hline \multirow[t]{2}{*}{ Vakum_gagal } & Ya & 0 & 0 & 2 & 100 & 6,458 & $0,995-41,900$ & 0,936 \\
\hline & Tidak & 5 & 3,3 & 148 & 96,7 & & & \\
\hline \multirow[t]{2}{*}{ Persalinan_lama } & Ya & 2 & 5,9 & 32 & 94,1 & 2,373 & $0,413-13,630$ & 0,302 \\
\hline & Tidak & 3 & 2,5 & 118 & 97,5 & & & \\
\hline
\end{tabular}

Tabel 11. Hasil analisis multivariat metode

\begin{tabular}{lcccccc}
\hline \multirow{2}{*}{ Variabel } & \multicolumn{2}{c}{$\begin{array}{c}\text { Skor Apgar } \leq 3 \\
\text { menit 1 }\end{array}$} & \multicolumn{2}{c}{$\begin{array}{c}\text { Skor Apgar }<7 \\
\text { menit 5 }\end{array}$} & \multicolumn{2}{c}{ CPAP } \\
\cline { 2 - 7 } & $\mathbf{P}$ & OR (IK 95\%) & $\mathbf{p}$ & OR (IK 95\%) & $\mathbf{P}$ & OR (IK 95\%) \\
\hline Prematuritas & $0,040^{*}$ & 3,274 & $0,025^{*}$ & 3,370 & $0,009 *$ & 4,576 \\
& & $(1,057-10,136)$ & & $(1,16-9,78)$ & & $(1,47-14,26)$ \\
Anestesi GA & & & $0,044^{*}$ & 4,950 & & \\
& & & & $(1,04-23,4)$ & & \\
\hline
\end{tabular}

Dari analisis bivariat didapatkan tidak memiliki hubungan bermakna antara faktor-faktor yang diteliti yaitu skor Apgar $\leq 3$ menit 1 dengan operasi/SC, ketuban pecah dini, persalinan lama, vakum ekstraksi gagal dan response time. Jenis anestesi mempengaruhi luaran perinatal skor Apgar $\leq 3$ menit 1 dengan nilai $p=0,044$ (RR 3,934, IK 95\% dengan 1,41-10,96) dan skor Apgar <7 menit 5 nilai $p=0,015$ (RR 4,083, IK 95\% 1,804$9,243)$. Sedangkan prematuritas mempengaruhi luaran perinatal skor Apgar $\leq 3$ menit 1 dengan nilai $p=0,028$ (RR 2,977, IK 95\% 1,217-7,283), skor Apgar $<7$ menit 5 nilai $p=0,008$ (RR 3,119, IK 95\% 1,471-6,615) dan penggunaan CPAP dengan nilai $\mathrm{p}=0,009$ (Relative Risk 3,473, IK 95\% 1,497$8,060)$.

Pada hasil analisis multivariat dengan metode backward dari semua variabel, didapatkan pada step terakhir yang berpengaruh bermakna secara statistik dengan luaran perinatal adalah variabel jenis anestesi GA mempengaruhi skor Apgar $<7$ 
menit 5 dan adanya prematuritas ( $<37$ minggu) mempengaruhi skor Apgar $\leq 3$ menit 1, skor Apgar $<7$ menit 5 dan penggunaan CPAP. Sedangkan untuk variabel lain termasuk response time tidak berpengaruh bermakna secara statistik terhadap luaran perinatal.

Response time pada penelitian ini masih jauh dari yang direkomendasikan yaitu 30 menit. Hal ini telah diterangkan oleh beberapa penelitian,dimana response time sesuai rekomendasi 30 menit untuk seksio sesarea emergensi kategori 1 secara praktis memang sulit diaplikasikan. ${ }^{3}$ Alasannya biasanya karena keterlambatan pembiusan, tidak lengkapnya tim operasi, kamar operasi yang penuh, dan transfer pasien dari ruangan ke kamar operasi. ${ }^{4,5}$ Di RSUP Dr. Sardjito, response time seksio sesarea emergensi sendiri khususnya untuk kategori 1 membutuhkan waktu yang lebih lama dikarenakan berbagai sebab antara lain kamar operasi yang penuh, tim operasi yang tidak lengkap, lamanya mendapatkan persetujuan dokter anestesi, menunggu tim perinatologi, pemeriksaan laboratorium yang lama, transfer pasien dari ruangan atau IGD ke kamar operasi. Bahkan 1 kasus dimana response time SC emergensi kategori 1360 menit, hal ini terjadi karena ruang operasi yang sibuk disebabkan adanya operasi yang bersamaan dengan teman sejawat bedah. Sehingga perlu dilakukan penelitian selanjutnya untuk menganalisis faktor faktor yang memperlambat response time, sehingga dapat dilakukan perbaikan untuk mencapai target waktu yang direkomendasikan sesuai guideline dan standar pelayanan operasional RSUP Dr. Sardjito.

Pada penelitian saat ini menunjukkan bahwa luaran perinatal (skor Apgar $\leq 3$ menit 1, Apgar $<7$ menit 5, CPAP, kematian bayi, ventilator, perawatan NICU, MAS dan HIE) secara statistik tidak ditemukan perbedaan bermakna antara kelompok seksio sesarea emergensi kategori 1 interval waktu $\geq 115$ menit dibandingkan dengan interval waktu $<115$ menit. Hasil ini hampir sama dengan penelitian yang dilakukan oleh Bloom et al., dimana mereka melakukan studi observasional prospektif dari tahun 1999 sampai dengan 2002, dari 11.481 persalinan dengan seksio sesarea primer, 2.808 kasus dilakukan atas indikasi emergensi berkesimpulan bahwa mendekati sepertiga seksio sesarea emergensi yang dilakukan dengan interval lebih dari 30 menit setelah pengambilan keputusan dengan sebagian besar indikasi non reasuring fetal heart rate tidak didapatkan peningkatan morbiditas neonatal. ${ }^{6}$ Bahkan dari studi di Nigeria, dilaporkan rerata response time seksio sesarea emergensi sampai 200 menit namun tidak memberikan pengaruh yang bermakna terhadap luaran perinatal. ${ }^{5}$

Pada analisis bivariat, pengaruh beberapa variabel luar terhadap luaran perinatal banyak yang memiliki nilai Relative Risk (RR) yang tinggi namun secara statistik tidak bermakna, salah satunya adalah engaruh persalinan lama dengan terjadinya HIE dengan ( $p=0,302$ (RR 2,373; IK 95\% 0,413-13,630). Hasil tersebut mungkin dapat disebabkan karena jumlah subjek penelitian yang masih sedikit untuk mendapatkan hasil yang bermakna.

Sedangkan dari analisis multivariat variabel luar jenis anestesi bermakna secara statistik terhadap luaran perinatal skor Apgar $<7$ menit 5 ( $p=0,044 ;$ Odds ratio 4,950, IK 95\% 1,04-23,4) dan tidak bermakna secara statistik terhadap luaran perinatal yang lain. Jenis anestesi yang paling berpengaruh pada penelitian ini terhadap luaran perinatal skor Apgar $<7$ menit 5 adalah jenis anestesi umum atau general anaesthesia (GA) dibandingkan dengan anestesi spinal yang dapat dilihat dari analisis bivariat. Hasil tersebut sejalan dengan penelitian yang dilakukan oleh Loho dan Siswosudarmo, dimana didapatkan pengaruh jenis anestesi GA, morbiditas lebih tinggi yaitu $61.5 \%$ berbanding $29 \%$ pada anestesi 
regional (RR=2.12, IK 95\% $1.41-3.20) .^{7}$ Selain itu general anaesthesia (GA) telah dihubungkan dengan morbiditas neonatal jangka pendek pada seksio sesarea emergensi kategori 1 dengan indikasi fetal compromise. ${ }^{8}$

Dari analisis multivariat lainnya diketahui variabel prematuritas secara statistik mempengaruhi luaran perinatal yaitu skor Apgar $\leq 3$ menit 1 dengan $p=0,040$ (OR 3,274; IK 95\% 1,057-10,136), skor Apgar <7 menit 5 dengan nilai $p=0,025$ (OR 3,370; IK 95\% 1,16-9,78) dan penggunaan CPAP dengan nilai $p=0,009$ (OR 4,576; IK 95\% 1,47-14,26). Pada penelitian ini prematuritas yang ada mulai dari usia kehamilan 34 minggu hingga 36 minggu (late preterm). Pada usia kehamilan late preterm mempunyai kecenderungan morbiditas yang lebih tinggi dibandingkan dengan bayi yang lahir cukup bulan. Angka mortalitas neonatal bayi late preterm 3x lipat lebih tinggi dibandingkan bayi cukup bulan (7.7 vs 2.5 per 1000 kelahiran hidup). ${ }^{9}$

Tidak adanya perbedaan bermakna secara statistik antara response time dengan luaran perinatal pada penelitian yang dilakukan dapat dikarenakan tindakan resusitasi terhadap neonatal saat intrauterin maupun pascapersalinan. Roy et al., pada penelitiannya mengemukakan response time $>30$ menit tidak berpengaruh terhadap luaran perinatal. Janin dengan response time $>30$ menit dimungkinkan mendapatkan resusitasi intrauterin melalui tindakan posisi ibu miring kiri, pemberian hidrasi dengan infus, dan pemberian oksigen pada ibu. Hal ini dapat memperbaiki kondisi hipoksia janin ke arah perbaikan hingga batas tertentu sampai dilakukannya seksio sesarea emergensi. Namun begitu tidak dapat disimpulkan bahwa response time $>30$ menit bisa diterima sebagai suatu yang ideal. ${ }^{10}$

Meskipun monitoring jantung janin secara elektronik dengan kardiotokografi (CTG) telah dikenalkan sejak 30 tahun yang lalu, manfaat terhadap luaran perinatal jangka panjang dan kejadian seksio sesarea meningkat $4 x$. Berbagai studi menunjukkan bahwa interpretasi CTG tidak konsisten, tidak akurat dan dapat gagal memprediksi luaran perinatal awal dan hal ini dipengaruhi oleh faktor medikolegal. ${ }^{10}$ Pada penelitian ini' $96,1 \%$ nya merupakan kasus fetal distress dimana penegakan diagnosis ini berdasarkan dari hasil CTG. Hal ini sama dengan laporan beberapa penelitian dari luar negeri. Sehingga pembacaan CTG menjadi penting, pembacaan yang tidak akurat dapat membuat diagnosis yang tidak tepat sehingga terlalu cepat diputuskan untuk seksio sesarea emergensi. Akhirnya memberikan hasil yang bermakna terhadap penelitian ini mengapa tidak adanya perbedaan yang bermakna secara statistik antara response time $\geq 115$ menit dengan yang $<115$ menit terhadap luaran perinatal.

\section{KESIMPULAN DAN SARAN}

Perbedaan waktu kecepatan response time seksio sesarea emergensi kategori 1 pada subjek penelitian ini tidak mempengaruhi luaran perinatal. Secara statistik tidak ada perbedaan bermakna luaran perinatal pada response time seksio emergensi kategori 1 yang <115 menit dengan $\geq 115$ menit di RSUP Dr. Sardjito. Jenis anestesi berpengaruh terhadap luaran perinatal skor Apgar $<7$ menit 5, sedangkan prematuritas berpengaruh terhadap luaran perinatal skor Apgar $\leq 3$ menit 1 , skor Apgar $<7$ menit 5 dan penggunaan CPAP.

\section{DAFTAR PUSTAKA}

1. National Collaborating Centre for Women's and Children's Health. Caesarean Section. NICE Clinical Guideline 2011; 282.

2. Zhang Q, Dunn CN, Sia JT, Sng BL. Category one caesarean section: a team based approach. Trends in Anaesthesia and Critical Care 2014; Vol 4(4): 97101. 
3. Helmy WH, Jolaoso AS, Ifaturoti OO, Afify SA, Jones $\mathrm{MH}$. The decision-to-delivery interval for emergency caesarean section: is 30 minutes a realistic target?. BJOG: An International Journal of Obstetrics and Gynaecology 2002; Vol 109(5): 505-508.

4. Onah HE, Ibeziako N, Umezulike AC, Effetie ER, Ogbuokiri CM. Decision-delivery interval \& perinatal outcome in emergency caesarean section. J Obstet Gynaecol 2005; Vol 25 (4): 342-346.

5. Tuffnell DJ, Wilkinson K, Beresford N. Interval between decision and delivery by caesarean section-are current standards achievable? Observational case series. BMJ (Clinical research ed.) 2001; Vol 322(7298): 1330-3.

6. Bloom SL, Leveno KJ, Spong CY, Gilbert S, Hauth JC, Landon MB, Varner MW, Moawad AH, Caritis SN, Harper M, Wapner RJ, Sorokin Y, Miodovnik M, O'Sullivan MJ, Sibai BM, Langer O, Gabbe SG. Decision-to-incision times and maternal and infant outcomes. In: ACOG, Obstet Gynecol 2006; Vol 108(1): 6-11.

7. Loho R, Siswosudarmo R. Pengaruh "response time" pada seksio sesarea emergensi terhadap luaran kehamilan di RS Sardjito, Tesis PPDS I Obstetrika dan Ginekologi Fakultas Kedokteran UGM. Yogyakarta, 2012.

8. Beckmann M, Calderbank S. Mode of anaesthetic for category 1 caesarean sections and neonatal outcomes. Aust N Z J Obstet Gynaecol 2012; Vol 52(4):316-320.

9. Loftin RW, Habli M, Snyder CC, Cormier CM, Lewis DF, DeFranco EA. Late Preterm Birth. Reviews in Obstetrics and Gynecology 2010; Vol 3(1): 10-19.

10. Roy KK, Baruah J, Kumar S, Deorari AK, Sharma JB, Karmakar D. Cesarean section for suspected fetal distress, continuous fetal heart monitoring and decision to delivery time. Indian Journal of Pediatrics 2008; Vol 75(385): 1249-1252. 